\title{
Enterohemorrhagic Escherichia coli with particular attention to the German outbreak strain O104:H4
}

\author{
Enterohemorragische E. coli met speciale aandacht voor de bij de Duitse \\ uitbraak betrokken stam O104:H4
}

\author{
${ }^{1}$ M.A. Joris, ${ }^{2}$ D. Vanrompay, ${ }^{3}$ K. Verstraete, ${ }^{3}$ K. De Reu, ${ }^{1}$ L. De Zutter \\ ${ }^{1}$ Department of Veterinary Public Health and Food Safety, Laboratory of Hygiene and Technology, \\ Faculty of Veterinary Medicine, Ghent University, Salisburylaan 133, 9820 Merelbeke, Belgium \\ ${ }^{2}$ Department of Molecular Biotechnology, Faculty of Bioscience Engineering, Ghent University, \\ Coupure Links 653, 9000 Gent, Belgium \\ ${ }^{3}$ Institute for Agricultural and Fisheries Research (ILVO), Technology and Food Science Unit - Food \\ safety, Brusselsesteenweg 370, 9090 Melle, Belgium \\ adelheid.joris@ugent.be
}

\begin{abstract}
This review deals with the epidemiology and ecology of enterohemorrhagic Escherichia coli (EHEC), a subset of the verocytotoxigenic Escherichia coli (VTEC), and subsequently discusses its public health concern. Attention is also given to the outbreak strain 0104:H4, which has been isolated as causative agent of the second largest outbreak of the hemolytic uremic syndrome worldwide, which started in Germany in May 2011. This outbreak strain is not an EHEC as such but possesses an unusual combination of EHEC and enteroaggregative $E$. coli $(\mathrm{EAggEC})$ virulence properties.
\end{abstract}

\section{SAMENVATTING}

In dit overzichtsartikel worden de epidemiologie en de ecologie van de enterohemorragische Escherichia coli (EHEC), een subset van de verocytotoxigene E. coli (VTEC) besproken en wordt het belang ervan voor de volksgezondheid toegelicht. Speciale aandacht wordt besteed aan de uitbraakstam O104:H4 die geïsoleerd werd als verwekker van de tweede grootste uitbraak van het hemolytische uremisch syndroom wereldwijd. Deze uitbraak begon in mei 2011 in Duitsland maar hield heel Europa in de ban. Deze stam is echter geen EHEC als dusdanig, maar bezit een ongewone combinatie van virulentiefactoren van zowel EHEC als enteroaggregatieve E. coli.

\section{INTRODUCTION}

Most Escherichia coli are harmless commensals of the gastrointestinal flora of warm-blooded animals and humans. However, some subsets of $E$. coli have acquired virulence properties that render them capable of causing a variety of clinical outcomes in humans and animals. Most acquired virulence factors that distinguish pathogenic $E$. coli from harmless $E$. coli are encoded on mobile genetic elements capable of horizontal gene transfer or on elements that were once mobile and subsequently evolved to be a stable part of the genome (Kaper et al., 2004). The intestinal E. coli pathogens can be divided into six well defined pathotypes: enterohemorrhagic $E$. coli (EHEC), enteropathogenic $E$. coli (EPEC), enterotoxigenic E. coli (ETEC), enteroaggregative $E$. coli (EAggEC), diffusely adherent $E$. coli (DAEC), and enteroinvasive E. coli (EIEC) (Nataro and Kaper, 1998). The differences between these pathotypes are not discussed in this review since the focus is on the EHEC pathotype and the enteroaggregative verotoxin-producing $E$. coli O104:H4 outbreak strain.

\section{PATHOGENIC FEATURES AND VIRULENCE FACTORS OF EHEC}

EHEC denotes strains that are associated with hemorrhagic colitis and the hemolytic uremic syndrome in humans, and express verocytotoxins and colonize the intestine by causing typical attaching-effacing (A/E) lesions (Nataro and Kaper, 1998). The majority of clinical cases have been caused by strains belonging to the O157:H7 serotype. However, there are a number of non-O157 serogroups of which the 4 deemed most important in terms of clinical infections are $\mathrm{O} 26$, O103, O111 and O145. Nevertheless, there are many other serogroups, such as O91, O121 and recently O104, which have also caused infections.

\section{Verocytotoxins}

The cardinal trait of EHEC is the production of verocytotoxins. The definition is based upon the production of toxins with a cytotoxic activity against vero cells. There are two main types, namely VT1 and VT2 that can be further divided into subtypes based on their 
sequence analyses. The nomenclature is not definite and new variants are constantly being described. The VT1 family can be divided into three subtypes, namely VT1, VT1c and VT1d (Muthing et al., 2009). The VT2 is more heterogeneous and up to now, it has been divided into 7 subtypes, namely VT2, VT2b, VT2c, VT2d, VT2e, Vt2f and VT2g (Mainil and Daube, 2005; Persson et al., 2007). The VT-encoding genes (vtx) are generally encoded by a heterogeneous group of temperate lambdoid bacteriophages and are expressed when the lytic cycle is activated (Allison, 2007; Herold et al., 2004). The VT-encoding $v t x 2 \mathrm{e}$ was initially thought to be chromosomally encoded (Paton and Paton, 1998). However, a vtx2e converting bacteriophage has been isolated (Muniesa et al., 2000). Several studies have demonstrated a correlation between the toxin subtypes, severity of clinical diseases and seropathotypes. In general, EHEC producing VT2 only, generally cause more severe disease than those producing lonely VT1 or both VT1 and VT2 (Table 1).

Although the production of VT is considered a main virulence factor of EHEC, strains of non-verocytotoxin producing E. coli $\mathrm{O} 157: \mathrm{H}^{-}$have been isolated from patients with HUS or diarrhoea (Schmidt et al. 1999b). However, Joris et al. (2011) have demonstrated the spontaneous loss of $v t x$ genes during isolation. This might complicate the characterization of the virulence patterns of these strains. They can appear to be vtx ne- gative but clinically and epidemiologically they are originally $v t x$ positive strains.

All VT belong to the $\mathrm{AB}_{5}$ family of toxins, with the A subunit carrying the enzymatic activity and a pentameric receptor-binding $\mathrm{B}$ subunit. The pentameric $\mathrm{B}$ subunit binds specifically to the globotriaosylceramide (Gb3) and globotetraosylceramide (Gb4) receptor. The Gb4 receptor is preferred by the VT2e, whereas all other VT variants prefer Gb3 (Boyd et al., 1993; Lingwood et al., 1998). After binding to the receptor, Vt are internalized by a clathrin-mediated endocytosis and transported via the Golgi-apparatus to the endoplasmatic reticulum (Sandvig et al., 1992). In the cytosol, the A subunit is cleaved by a protease, furin, into a catalytically active A1 fragment and an A2 fragment. The A1 fragment exerts tRNA N-glycosidase activity that specifically removes an adenine residue from the 28S rRNA of the 60S ribosome (Endo et al., 1988). This process inhibits protein synthesis and leads to cell death.

\section{Locus of enterocyte effacement}

The hallmark of EHEC strains is the induction of $\mathrm{A} / \mathrm{E}$ lesions, which are characterized by localized destruction of brush border microvilli and intimate attachment to the plasma membrane of host epithelial cells. EHEC strains share the induction of A/E lesions

Table 1. Different types of VT (adapted from Gyles, 2007).

\begin{tabular}{|c|c|c|}
\hline VT variants & Characteristics & Reference \\
\hline Vtx1 & $\begin{array}{l}\text { VT produced by VTEC and almost identical to Stx produced by } \\
\text { Shigella dysenteriae serotype } 1\end{array}$ & (Strockbine et al., 1986) \\
\hline Vtx1c & $\begin{array}{l}\text { Variant of Vtx1 that is found in ovine and caprine strains } \\
\text { but not in bovine strains and in some eae-negative VTEC; } \\
\text { associated with mild diarrhoea or no symptoms }\end{array}$ & $\begin{array}{l}\text { (Brett et al., 2003; } \\
\text { Zhang et al., 2002) }\end{array}$ \\
\hline Vtx1d & $\begin{array}{l}\text { A variant of Vtx } 1 \text { isolated from bovine and human strains; } \\
\text { associated with asymptomatic infections }\end{array}$ & (Burk et al., 2003) \\
\hline $\operatorname{Vtx} 2$ & Prototype of non-Vtx1 toxins; associated with severe disease in humans & (Strockbine et al., 1986) \\
\hline $\mathrm{Vtx} 2 \mathrm{c}$ & $\begin{array}{l}\text { Associated with diarrhoea and HUS in humans; common in bovine } \\
\text { and ovine VTEC }\end{array}$ & $\begin{array}{l}\text { (Friedrich et al., } \\
\text { 2002; Pierard et al., } \\
\text { 1998; Schmitt et al., 1991) }\end{array}$ \\
\hline $\mathrm{Vt} 2 \mathrm{~d}$ & Associated with eae-negative VTEC and mild disease in human & $\begin{array}{l}\text { (Friedrich et al., 2002; } \\
\text { Pierard et al., 1998) }\end{array}$ \\
\hline Vtx2dact & $\begin{array}{l}\text { Vero cell cytotoxicity is increased by elastase in intestinal mucus; } \\
\text { these strains are highly virulent }\end{array}$ & (Kokai-Kun et al., 2000) \\
\hline Vtx2e & $\begin{array}{l}\text { A variant responsible for oedema disease of pigs; rare in human } \\
\text { disease and associated with mild diarrhoea or asymptomatic } \\
\text { infections in humans }\end{array}$ & $\begin{array}{l}\text { (Gyles et al., 1988; } \\
\text { Sonntag et al., 2005a) }\end{array}$ \\
\hline Vtx2f & A variant frequently isolated from pigeon droppings; rare in human disease & (Sonntag et al., 2005b) \\
\hline Vtx2g & A variant isolated from bovine strains; to date not associated with human disease & (Leung et al., 2003) \\
\hline
\end{tabular}


with EPEC strains. The locus of enterocyte effacement (LEE), which is constituted of three functionally different components, is the genetic element responsible for the formation of A/E lesions. The first encodes a type three secretion system (TTSS) that exports effector proteins. The second encodes the structural components of the type three secretion apparatus, namely the secreted proteins EspA, B and D. The third encodes the 94-kDA outer-membrane protein intimin, encoded by eae, which mediate the intimate attachment of EHEC to the intestinal epithelial cells and its translocated receptor Tir, which is directly inserted in the host cell membrane.

\section{EHEC IN HUMANS}

EHEC infections in humans are associated with a broad spectrum of clinical outcomes ranging from symptom-free infection through watery diarrhoea, to severe hemorrhagic colitis (HC) and hemolytic uremic syndrome (HUS). The incubation period is three days (ranging between 1-12 days) (Tarr et al., 2005). Characteristically, patients suffer the first three days from watery diarrhoea, abdominal cramps and occasionally nausea and vomiting. In $90 \%$ of the cases, this diarrhoea becomes hemorrhagic within one to three days. When bloody diarrhoea develops, the patients has a normal platelet count, creatinine concentration and packed-cell volume with no erythrocyte fragmentation (Tarr et al., 2005). In most cases, recovery from illness usually occurs spontaneously over approximately one week. However, the infection can evolve to the life-threatening HUS. The classic triad of features for HUS consists of acute renal failure, microangiopathic hemolytic anemia, and thrombocytopenia. The major risk factors for acquiring HUS include extremes of age $(<15$ years or $>$ 65 years) (Dundas and Todd, 2000), early neutrophilia, hypoalbuminemia (Dundas et al., 2001), increased C reactive protein level, fever within the first three days of illness (Ikeda et al., 2000) and the administration of antibiotics and antimotility agents (Wong et al., 2000). The mortality from HUS is between $3-17 \%$, however in the elderly, it is as high as $87 \%$ (Griffin and Tauxe, 1991). While the kidney is the organ most commonly affected in HUS, evidence of central nervous system, pancreatic, skeletal and myocardial involvement may also be present (Richardson et al., 1988; Sebbag et al., 1999; Siegler, 1994). Pancreatic involvement, indicated by insulin-dependent diabetes mellitus and the increase of pancreatic enzymes, arises in less than $10 \%$ of the cases (Andreoli and Bergstein, 1982). The involvement of the central nervous system occurs in up to $25 \%$ of the cases and can lead to irritability, learning disabilities, lethargy and seizures and in sporadic cases to cerebral edema and coma (Amirlak and Amirlak, 2006; Elliott and Robins-Browne, 2005).

\section{RESERVOIR HOSTS OF EHEC}

EHEC are usually found in the colon epithelium of ruminants, among which cattle are recognized to be the main reservoir. Carriage rates in cattle appear to be particularly high (ranging from 0.2 to $70.1 \%$ ) (Hussein and Bollinger, 2005) and contamination of foodstuffs from these animals has been highlighted as a major source of human infections. However, EHEC has been isolated from other food-producing, domestic and wild animals. In addition to the potential for foods derived from animals becoming contaminated with EHEC, animals themselves can act as vectors for the spreading of EHEC in the environment and to humans.

\section{Cattle}

Cattle are generally regarded as the main natural reservoir of EHEC. Although most of the EHEC strains do not cause disease in cattle, some serogroups such as $\mathrm{O} 5, \mathrm{O} 26$ and $\mathrm{O} 118$ are associated with diarrhoea in calves (Mainil, 1999). The apparent resistance of cattle to systemic effects of VT may be due to the distinct pattern of $\mathrm{Gb}_{3}$ receptors in their kidneys and the $\mathrm{ab}$ sence of receptors on vasculature (Hoey et al., 2002). Shedding of EHEC in cattle has been shown to be intermittent. Most animals that test positive for EHEC become fecal culture negative within two or three months (Besser et al., 1997; Rahn et al., 1997). Nevertheless, while shedding among cattle appears transiently, EHEC infection maintains in cattle herds (Wells et al., 1991). All ages of cattle are susceptible to colonization with EHEC, although peak shedding is observed in subadult cattle from weaning to 24 months of age (Hussein and Sakuma, 2005). The prevalence can also be affected by the season, with higher rates being reported during spring and summer. This seasonal effect has long been theorized to be related to the increased proliferation of EHEC in the environment during warm weather (Hancock et al., 1994; Heuvelink et al., 1998b). However, a recent hypothesis has emerged that day length and physiological responses within the animal to changing day length may explain the seasonal shedding patterns (Edrington et al., 2006). The study showed that after a period of 60 days, there was a significant difference in shedding in the lighted pens compared to control groups with no light-treatment. Once the light-treatment was removed from the test group, shedding decreased to levels equivalent to the control group.

\section{Other ruminants}

Small ruminants, such as sheep and goats, are also known carriers of E. coli $\mathrm{O} 157$ and non-O157. Compared with cattle, higher prevalence rates for EHEC have been found in sheep and goats. Beutin et al. (1993) demonstrated prevalence rates of $56 \%$ in goats, $67 \%$ in sheep compared to $18 \%$ in cattle. In Australia, in $88 \%$ of fecal samples from sheep grazing on pasture vtx genes were detected (Fegan and Desmarchelier, 1999). Ovine strains belong in general to six serogroups, namely O6, O91, O117, O128, O146 and O166 (Heuvelink et al., 1998a; Urdahl et al., 2003). The water buffalo is another potential source of EHEC in- 
fections. A recent survey conducted in Italy has demonstrated that buffalo herds are often colonized by $E$. coli $\mathrm{O} 157$ (Galiero et al., 2005). Based on the current preliminary prevalence rates, it is reasonable to assume small ruminants to be a potential source of human EHEC infections. However, given the preliminary character of the prevalence rates, further research may be warranted.

\section{Non-ruminants}

EHEC have been occasionally isolated from animals other than ruminants. In many cases, it is not clear whether they are actual hosts of the bacteria or merely act as vectors after contact with contaminated feces (Wasteson, 2008; Wasteson et al., 1999; Wasteson et al., 1992). Johnsen et al. (2001) isolated E. coli $\mathrm{O} 157$ in $0.1 \%$ from pigs raised at farms that also bread cattle. In the United States, a recovery rate of $2 \%$ was observed from colon fecal samples of pigs. E. coli $\mathrm{O} 157$ has also been isolated from horses, cats and dogs. In all cases, these animals are housed on farms which also house cattle (Chalmers et al., 1997; Trevena et al., 1996).

\section{Wild animals}

Besides from domestic animals, EHEC have been isolated from a variety of wild animals, such as rabbits and deer. In the United Kingdom, visitors to a wildlife park became infected with EHEC O157. This outbreak was associated with feces from wild rabbits, living in an adjacent field together with E. coli O157 positive cattle. This outbreak revealed that wild rabbits can also act as vectors. Fischer et al. (2001) detected EHEC $\mathrm{O} 157$ in $0.6 \%$ of the feces of white-tailed deer. The consumption of jerky made from deer meat has also been associated with human infections (Keene et al., 1997). These outbreaks associated with wild animals highlight the potential role that wild animals can play in the transmission of EHEC.

\section{TRANSMISSION OF EHEC}

There are four main transmission routes identified through which EHEC can be transmitted to humans: (1) foodborne transmission; (2) waterborne transmission; (3) person-to-person transmission; and (4) direct contact with animals.

\section{Foodborne transmission}

Most outbreaks of EHEC infections are caused by inadequately cooked hamburgers or other beef products, and unpasteurized milk. Dairy products associated with outbreaks are those that are unpasteurized, had a pasteurization failure or were contaminated after pasteurization. The latter can be illustrated by a ice cream-related outbreak in Belgium (Buvens et al., 2011). Over the last years, the contribution of other food vehicles has increased. For example, outbreaks have been associated with fermented sausages, apple juice, mayonnaise and yoghurt. These outbreaks highlight the acid tolerance and the ability to survive the process of fermentation and drying of EHEC O157 strains. Fresh produce can be contaminated by direct contact with fecally contaminated soil, agricultural run-off or irrigation water. Noteworthy, the use of agricultural run-off water for irrigation is prohibited in Europe. In 2006, a multistate outbreak of E. coli $\mathrm{O} 157$ occurred in the United States. Fresh baby spinach, contaminated by feces of wild boars, was identified as the source of the outbreak, involving 183 persons (Jay et al., 2007).

\section{Waterborne transmission}

Water is a very efficient vehicle for the dissemination of EHEC. Surface waters may be subjected to EHEC contamination through run-off from pastures and from direct deposition of fecal material on the agricultural land. Water close to cattle herds may therefore present a potential reservoir of EHEC allowing the pathogen to spread in the environment. For example, in many countries, the river water is contaminated with a huge load of treated and untreated manure. Recently, E. coli O157:H7 has been detected in the Ganges River (Hamner et al., 2007). Contaminated water as a source of EHEC infection may occur as a result of drinking (Bopp et al., 2003; Olsen et al., 2002) and swimming water (Samadpour et al., 2002). The largest waterborne outbreak occurred in Canada in 2000. The outbreak led to seven deaths and more than 2300 illnesses (Hrudey et al., 2003). The drinking water supply was contaminated by rainwater run-off containing cattle feces. Several of the drinking water outbreaks occurred in water systems without proper chlorination.

\section{Person-to-person transmission}

Since the infectious dose is low ( 1 to 100 cells) person-to-person can easily occur through fecal-oral transmission following a primary case). Person-to-person transmission has emerged in day-care facilities as the predominant route of EHEC outbreaks (O'Donnell et al., 2002; Reida et al., 1994). It has been demonstrated that infected humans may shed EHEC for several weeks following resolution of the clinical features (Mead and Griffin, 1998). This prolonged shedding tends to be more pronounced in young children, explaining the outbreaks in day-care facilities. Furthermore, EHEC infections can occur asymptomatically. Secondary transmission by the primary case in a household is therefore a particular concern.

\section{Contact with animals}

Several EHEC outbreaks have been associated with animal exhibits at fairs, zoos and other venues resulting from direct contact with the animals and their environment followed by inadequate hand washing. Contact with pets has also been a route of EHEC infection. In Germany, a 2-year-old girl with bloody diarrhoea was found to excrete EHEC. Repeated stool samples 
from her cat yielded a strain of EHEC O145:H- that showed the identical pathogenicity gen pattern as the girl's isolate. Although the cat had no symptoms, it excreted this strain for several months and was apparently the source of the girl's original infection and/or reinfection (Busch et al., 2007).

\section{OUTBREAK IN GERMANY, MAY 2011}

Early May 2011, an unusually high number of HUS cases were reported in Germany. The outbreak strain was in facto not an EHEC strain as repeatedly reported in popular media, but shared characteristics of EAEC and VTEC. Strains with combinations of virulence properties from different pathotypes have been described before, but the size and severity of the outbreak have highlighted the importance and unpredictability of the consequences of genetic exchange between pathotypes.

\section{The outbreak strain}

The outbreak strain has been characterized very thoroughly at the Robert Koch Institute. The strain is of serotype O104:H4 and evolves from a progenitor that belongs to the enteroaggregative pathotype. The emergence of the outbreak strain depends on the acquisition of a $v t x 2$ prophage and of a plasmid encoding CTX-M15 ESBL (Rohde et al., 2011). The outbreak strain possesses therefore an unusual combination of virulence factors of EAEC and EHEC. This combination is very rare and has previously been described in strains of serotype O111:H2 involved in a small outbreak of HUS in children in France (Morabito et al., 1998). It remains unclear why this strain has proven to be so virulent. However, it is conceivable that the enteroaggregative phenotype rendered these $\mathrm{O} 104: \mathrm{H} 4$ strains to colonize the intestinal mucosa as efficiently as the typical eae-positive EHEC strains. The augmented adherence of the strain to the intestinal epithelium might facilitate the systemic absorption of the verocytotoxins and could explain the high progression to HUS (Bielaszewska et al., 2011).

\section{Outbreak description}

On May 22th 2011, Germany reported a significant increase in patients with bloody diarrhoea and HUS. During the succeeding month, thousands of infections occurred resulting in 3128 non-HUS cases, 782 cases of HUS and 46 deaths. The Robert Koch Institute stated on July 26th the outbreak in Germany as officially over, as the last onset of disease to be attributed to the outbreak was reported on the $4^{\text {th }}$ of July 2011. Up to 125 infections with 49 cases of HUS caused by the outbreak strain have been reported in other European countries including, Austria, the Czech Republic, Denmark, France, Greece, Luxembourg, the Netherlands, Norway, Poland, Spain, Sweden and the United Kingdom. Most patients appeared to be travellers returning from Germany.
Of particular interest, O104:H4 cases showed an uneven sex distribution, with a preponderance of women in both non-HUS infections (59\%) and HUS $(68 \%)$ cases. In addition, people over 20 years of age account for the vast majority of the cases (88\%). This sex and age predominance might be related to genderspecific differences in dietary habits, namely vegetables are generally more often consumed by adult women. Other particular features of this outbreak are the high percentage of HUS cases (20-25\% instead of 5$6 \%$ ), common severe neurological complications and non-HUS deaths.

On June 24th, France also reported a cluster of $E$. coli O104:H4 infections among people who attended an open day at a children's community center in Bordeaux. All patients reported eating sprouts served at the event. The European Food Safety Agency (EFSA) conducted a comprehensive investigation to identify the source of the two outbreaks (EFSA, 2011). The analysis of the investigation identified a single lot of fenugreek seeds, from an exporter in Egypt, as the most likely source of the sprouts linked to the two outbreaks.

\section{CONCLUSION}

The knowledge of the epidemiology and ecology of EHEC is far from complete. To date, EHEC research has focused mainly on EHEC O157 in cattle. However, EHEC 0157 and non-O157 have been reported in many other animal species. New routes of transmission have also emerged, such as contact with animals during farm visits, contact with pets and a wide variety of environment-related exposures. In order to inform risk assessment, further research into non-bovine animal species, foodstuffs or environmental vehicles should be considered and tested.

The main conclusion from the German outbreak is that $E$. coli strains belonging to different pathotypes allowed for the emergence of the highly virulent verocytotoxin-producing enteroaggregative E. coli $\mathrm{O} 104: \mathrm{H} 4$ strain. Epidemiologists and microbiologists face many challenges of detecting strains belonging to different pathotypes and in preventing and managing future outbreaks of such strains.

\section{REFERENCES}

Allison, H.E., (2007). Stx-phages: Drivers and mediators of the evolution of stec and stec-like pathogens. Future Microbiology 2, 165-174.

Amirlak, I., Amirlak, B., (2006). Haemolytic uraemic syndrome: An overview. Nephrology 11, 213-218.

Andreoli, S.P., Bergstein, J.M., (1982). Development of insulin-dependent diabetes mellitus during the hemolyticuremic syndrome. The Journal of Pediatrics 100, 541-545.

Besser, T.E., Hancock, D.D., Pritchett, L.C., McRae, E.M., Rice, D.H., Tarr, P.I., (1997). Duration of detection of fecal excretion of Escherichia coli O157:H7 in cattle. Journal of Infectious Disease 175, 726-729.

Beutin, L., Geier, D., Steinruck, H., Zimmermann, S., Scheutz, F., (1993). Prevalence and some properties of verotoxin (shiga-like toxin)-producing Escherichia coli in 
seven different species of healthy domestic animals. Journal of Clinical Microbiology 31, 2483-2488.

Bielaszewska, M., Mellmann, A., Zhang, W., Kock, R., Fruth, A., Bauwens, A., Peters, G., Karch, H., (2011). Characterisation of the Escherichia coli strain associated with an outbreak of haemolytic uraemic syndrome in germany, 2011: A microbiological study. The Lancet Infectious Diseases 11, 671-676.

Bopp, D.J., Sauders, B.D., Waring, A.L., Ackelsberg, J., Dumas, N., Braun-Howland, E., Dziewulski, D., Wallace, B.J., Kelly, M., Halse, T., Musser, K.A., Smith, P.F., Morse, D.L., Limberger, R.J., (2003). Detection, isolation, and molecular subtyping of Escherichia coli O157:H7 and Campylobacter jejuni associated with a large waterborne outbreak. Journal of Clinical Microbiology 41, 174180.

Boyd, B., Tyrrell, G., Maloney, M., Gyles, C., Brunton, J., Lingwood, C., (1993). Alteration of the glycolipid binding specificity of the pig edema toxin from globotetraosyl to globotriaosyl ceramide alters in vivo tissue targetting and results in a verotoxin 1-like disease in pigs. The Journal of Experimental Medicine 177, 1745-1753.

Brett, K.N., Ramachandran, V., Hornitzky, M.A., Bettelheim, K.A., Walker, M.J., Djordjevic, S.P., (2003). Stx1c is the most common shiga toxin 1 subtype among shiga toxin-producing Escherichia coli isolates from sheep but not among isolates from cattle. Journal of Clinical Microbiology 41, 926-936.

Burk, C., Dietrich, R., Acar, G., Moravek, M., Bulte, M., Martlbauer, E., (2003). Identification and characterization of a new variant of shiga toxin 1 in Escherichia coli Ont:H19 of bovine origin. Journal of Clinical Microbio$\log y$ 41, 2106-2112.

Busch, U., Hormansdorfer, S., Schranner, S., Huber, I., Bogner, K.H., Sing, A., (2007). Enterohemorrhagic Escherichia coli excretion by child and her cat. Emerging Infectious Diseases 13, 348-349.

Buvens, G., Posse, B., De Schrijver, K., De Zutter, L., Lauwers, S., Pierard, D., (2011). Virulence profiling and quantification of verocytotoxin-producing Escherichia coli O145:H28 and O26:H11 isolated during an ice cream-related hemolytic uremic syndrome outbreak. Foodborne Pathogens and Disease 8, 421-426.

Chalmers, R.M., Salmon, R.L., Willshaw, G.A., Cheasty, T., Looker, N., Davies, I., Wray, C., (1997). Vero-cytotoxinproducing Escherichia coli $\mathrm{O} 157$ in a farmer handling horses. Lancet 349, 1816.

Dundas, S., Todd, W.T., (2000). Clinical presentation, complications and treatment of infection with verocytotoxinproducing Escherichia coli. Challenges for the clinician. Symposium Series, 24S-30S.

Dundas, S., Todd, W.T., Stewart, A.I., Murdoch, P.S., Chaudhuri, A.K., Hutchinson, S.J., (2001). The central scotland Escherichia coli O157:H7 outbreak: Risk factors for the hemolytic uremic syndrome and death among hospitalized patients. Clinical Infectious Diseases : An Official Publication of the Infectious Diseases Society of America 33, 923-931.

Edrington, T.S., Callaway, T.R., Ives, S.E., Engler, M.J., Looper, M.L., Anderson, R.C., Nisbet, D.J., (2006). Seasonal shedding ruminants of Escherichia coli $\mathrm{O} 157$ : H7 in a new hypothesis. Foodborne Pathogens and Disease 3, 413-421.

EFSA 2011. Tracing seeds, in particular fenugreek (trigonella foenum-graecum) seeds, in relation to the shiga toxin-producing E. coli (stec) O104:H4 2011 outbreaks in germany and france1 (Parma, EFSA).

Elliott, E.J., Robins-Browne, R.M., (2005). Hemolytic uremic syndrome. Current Problems In Pediatric and Adolescent Health Care 35, 310-330.

Endo, Y., Tsurugi, K., Yutsudo, T., Takeda, Y., Ogasawara, T., Igarashi, K., (1988). Site of action of a vero toxin (vt2) from Escherichia coli $\mathrm{O} 157: \mathrm{H} 7$ and of shiga toxin on eukaryotic ribosomes. RNA n-glycosidase activity of the toxins. European Journal of Biochemistry / FEBS 171, 4550.

Fegan, N., Desmarchelier, P., (1999). Shiga toxin-producing Escherichia coli in sheep and pre-slaughter lambs in eastern australia. Letters in Applied Microbiology 28, 335339.

Fischer, J.R., Zhao, T., Doyle, M.P., Goldberg, M.R., Brown, C.A., Sewell, C.T., Kavanaugh, D.M., Bauman, C.D., (2001). Experimental and field studies of Escherichia coli O157:H7 in white-tailed deer. Applied and Environmental Microbiology 67, 1218-1224.

Friedrich, A.W., Bielaszewska, M., Zhang, W.L., Pulz, M., Kuczius, T., Ammon, A., Karch, H., (2002). Escherichia coli harboring shiga toxin 2 gene variants: Frequency and association with clinical symptoms. The Journal of Infectious Diseases 185, 74-84.

Galiero, G., Conedera, G., Alfano, D., Caprioli, A., (2005). Isolation of verocytotoxin-producing Escherichia coli O157 from water buffaloes (bubalus bubalis) in Southern Italy. Veterinary Record 156, 382-383.

Griffin, P.M., Tauxe, R.V., (1991). The epidemiology of infections caused by Escherichia coli O157:H7, other enterohemorrhagic E. coli, and the associated hemolytic uremic syndrome. Epidemiologic Reviews 13, 60-98.

Gyles, C.L., (2007). Shiga toxin-producing Escherichia coli: An overview. Journal of Animal Science 85, E45-62.

Gyles, C.L., De Grandis, S.A., MacKenzie, C., Brunton, J.L., (1988). Cloning and nucleotide sequence analysis of the genes determining verocytotoxin production in a porcine edema disease isolate of Escherichia coli. Microbial Pathogenesis 5, 419-426.

Hamner, S., Broadaway, S.C., Mishra, V.B., Tripathi, A., Mishra, R.K., Pulcini, E., Pyle, B.H., Ford, T.E., (2007). Isolation of potentially pathogenic Escherichia coli O157:H7 from the Ganges River. Applied and Environmental Microbiology 73, 2369-2372.

Hancock, D.D., Besser, T.E., Kinsel, M.L., Tarr, P.I., Rice, D.H., Paros, M.G., (1994). The prevalence of Escherichia coli $\mathrm{O} 157 . \mathrm{H} 7$ in dairy and beef cattle in Washington State. Epidemiology and Infection 113, 199-207.

Herold, S., Karch, H., Schmidt, H., (2004). Shiga toxin-encoding bacteriophages - genomes in motion. International Journal of Medical Microbiology : IJMM 294, 115-121.

Heuvelink, A.E., van den Biggelaar, F.L., de Boer, E., Herbes, R.G., Melchers, W.J., Huis in 't Veld, J.H., Monnens, L.A., (1998a). Isolation and characterization of verocytotoxin-producing Escherichia coli 0157 strains from dutch cattle and sheep. Journal of Clinical Microbiology 36, 878-882.

Heuvelink, A.E., van den Biggelaar, F.L., Zwartkruis-Nahuis, J., Herbes, R.G., Huyben, R., Nagelkerke, N., Melchers, W.J., Monnens, L.A., de Boer, E., (1998b). Occurrence of verocytotoxin-producing Escherichia coli $\mathrm{O} 157$ on dutch dairy farms. Journal of Clinical Microbiology 36, 3480-3487.

Hoey, D.E., Currie, C., Else, R.W., Nutikka, A., Lingwood, C.A., Gally, D.L., Smith, D.G., (2002). Expression of receptors for verotoxin 1 from Escherichia coli $\mathrm{O} 157$ on bo- 
vine intestinal epithelium. Journal of Medical Microbio$\log y$ 51, 143-149.

Hrudey, S.E., Payment, P., Huck, P.M., Gillham, R.W., Hrudey, E.J., (2003). A fatal waterborne disease epidemic in walkerton, ontario: Comparison with other waterborne outbreaks in the developed world. Water Science And Technology : a Journal of the International Association on Water Pollution Research 47, 7-14.

Hussein, H.S., Bollinger, L.M., (2005). Prevalence of shiga toxin-producing Escherichia coli in beef cattle. Journal of Food Protection 68, 2224-2241.

Hussein, H.S., Sakuma, T., (2005). Shiga toxin-producing Escherichia coli: Pre- and postharvest control measures to ensure safety of dairy cattle products. Journal of Food Protection 68, 199-207.

Ikeda, K., Ida, O., Kimoto, K., Takatorige, T., Nakanishi, N., Tatara, K., (2000). Predictors for the development of haemolytic uraemic syndrome with Escherichia coli O157:H7 infections: With focus on the day of illness. Epidemiology and Infection 124, 343-349.

Jay, M.T., Cooley, M., Carychao, D., Wiscomb, G.W., Sweitzer, R.A., Crawford-Miksza, L., Farrar, J.A., Lau, D.K., O'Connell, J., Millington, A., Asmundson, R.V., Atwill, E.R., Mandrell, R.E., (2007). Escherichia coli O157:H7 in feral swine near spinach fields and cattle, Central California Coast. Emerging Infectious Diseases 13, 19081911.

Johnsen, G., Wasteson, Y., Heir, E., Berget, O.I., Herikstad, H., (2001). Escherichia coli O157:H7 in faeces from cattle, sheep and pigs in the southwest part of Norway during 1998 and 1999. International Journal of Food Microbiology 65, 193-200.

Joris, M.A., K. Verstraete, K. De Reu, L. De Zutter, (2011). Loss of vtx genes after the first subcultivation step of verocytotoxigenic Escherichia coli o157 and non-o157 during isolation from naturally contaminated fecal samples. Toxins 3, 672-677.

Kaper, J.B., Nataro, J.P., Mobley, H.L., (2004). Pathogenic Escherichia coli. Nature reviews. Microbiology 2, 123140.

Keene, W.E., Sazie, E., Kok, J., Rice, D.H., Hancock, D.D., Balan, V.K., Zhao, T., Doyle, M.P., (1997). An outbreak of Escherichia coli $\mathrm{O} 157: \mathrm{H7}$ infections traced to jerky made from deer meat. JAMA : Journal of the American Medical Association 277, 1229-1231.

Kokai-Kun, J.F., Melton-Celsa, A.R., O’Brien, A.D., (2000). Elastase in intestinal mucus enhances the cytotoxicity of shiga toxin type $2 \mathrm{~d}$. The Journal of Biological Chemistry 275, 3713-3721.

Leung, P.H., Peiris, J.S., Ng, W.W., Robins-Browne, R.M., Bettelheim, K.A., Yam, W.C., (2003). A newly discovered verotoxin variant, vt $2 \mathrm{~g}$, produced by bovine verocytotoxigenic Escherichia coli. Applied and Environmental Microbiology 69, 7549-7553.

Lingwood, C.A., Khine, A.A., Arab, S., (1998). Globotriaosyl ceramide (gb3) expression in human tumour cells: Intracellular trafficking defines a new retrograde transport pathway from the cell surface to the nucleus, which correlates with sensitivity to verotoxin. Acta biochimica Polonica 45, 351-359.

Mainil, J., (1999). Shiga/verocytotoxins and shiga/verotoxigenic Escherichia coli in animals. Veterinary Research 30, 235-257.

Mainil, J.G., Daube, G., (2005). Verotoxigenic Escherichia coli from animals, humans and foods: Who's who? Journal of Applied Microbiology 98, 1332-1344.
Mead, P.S., Griffin, P.M., (1998). Escherichia coli O157:H7. Lancet 352, 1207-1212.

Morabito, S., Karch, H., Mariani-Kurkdjian, P., Schmidt, H., Minelli, F., Bingen, E., Caprioli, A., (1998). Enteroaggregative, shiga toxin-producing Escherichia coli O111:H2 associated with an outbreak of hemolytic-uremic syndrome. Journal of Clinical Microbiology 36, 840-842.

Muniesa, M., Recktenwald, J., Bielaszewska, M., Karch, H., Schmidt, H., (2000). Characterization of a shiga toxin 2econverting bacteriophage from an Escherichia coli strain of human origin. Infection and Immunity 68, 4850-4855.

Muthing, J., Schweppe, C.H., Karch, H., Friedrich, A.W., (2009). Shiga toxins, glycosphingolipid diversity, and endothelial cell injury. Thrombosis and Haemostasis 101, 252-264.

Nataro, J.P., Kaper, J.B., (1998). Diarrheagenic Escherichia coli. Clinical Microbiological Reviews 11, 142-201.

O’Donnell, J.M., Thornton, L., McNamara, E.B., Prendergast, T., Igoe, D., Cosgrove, C., (2002). Outbreak of vero cytotoxin-producing Escherichia coli $\mathrm{O} 157$ in a child day care facility. Communicable Disease and Public Health / PHLS 5, 54-58.

Olsen, S.J., Miller, G., Breuer, T., Kennedy, M., Higgins, C., Walford, J., McKee, G., Fox, K., Bibb, W., Mead, P., (2002). A waterborne outbreak of Escherichia coli O157:H7 infections and hemolytic uremic syndrome: Implications for rural water systems. Emerging Infectious Diseases 8, 370375.

Paton, A.W., Paton, J.C., (1998). Detection and characterization of shiga toxigenic Escherichia coli by using multiplex pcr assays for stx1, stx2, eaea, enterohemorrhagic E. coli hlya, rfbo111, and rfbo157. Journal of Clinical Microbiology 36, 598-602.

Persson, S., Olsen, K.E., Ethelberg, S., Scheutz, F., (2007). Subtyping method for Escherichia coli shiga toxin (verocytotoxin) 2 variants and correlations to clinical manifestations. Journal of Clinical Microbiology 45, 20202024.

Pierard, D., Muyldermans, G., Moriau, L., Stevens, D., Lauwers, S., (1998). Identification of new verocytotoxin type 2 variant b-subunit genes in human and animal Escherichia coli isolates. Journal of Clinical Microbiology 36, 3317-3322.

Rahn, K., Renwick, S.A., Johnson, R.P., Wilson, J.B., Clarke, R.C., Alves, D., McEwen, S., Lior, H., Spika, J., (1997). Persistence of Escherichia coli O157:H7 in dairy cattle and the dairy farm environment. Epidemiology and Infection 119, 251-259.

Reida, P., Wolff, M., Pohls, H.W., Kuhlmann, W., Lehmacher, A., Aleksic, S., Karch, H., Bockemuhl, J., (1994). An outbreak due to enterohaemorrhagic Escherichia coli O157:H7 in a children day care centre characterized by person-to-person transmission and environmental contamination. Zentralblatt für Bakteriologie: International Journal of Medical Microbiology 281, 534-543.

Richardson, S.E., Karmali, M.A., Becker, L.E., Smith, C.R., (1988). The histopathology of the hemolytic uremic syndrome associated with verocytotoxin-producing Escherichia coli infections. Human Pathology 19, 1102-1108.

Rohde, H., Qin, J.J., Cui, Y.J., Li, D.F., Loman, N.J., Hentschke, M., Chen, W.T., Pu, F., Peng, Y.Q., Li, J.H., Xi, F., Li, S.H., Li, Y., Zhang, Z.X., Yang, X.W., Zhao, M.R., Wang, P., Guan, Y.L., Cen, Z., Zhao, X.N., Christner, M., Kobbe, R., Loos, S., Oh, J., Yang, L., Danchin, A., Gao, G.F., Song, Y.J., Li, Y.R., Yang, H.M., Wang, J., Xu, J.G., Pallen, M.J., Wang, J., Aepfelbacher, M., Yang, R.F., 
Crowd-Sourcing, E.c.O.H.G.A., (2011). Open-source genomic analysis of shiga-toxin-producing $E$. coli $\mathrm{O} 104: \mathrm{H} 4$. New England Journal of Medicine 365, 718-724.

Samadpour, M., Stewart, J., Steingart, K., Addy, C., Louderback, J., McGinn, M., Ellington, J., Newman, T., (2002). Laboratory investigation of an E. coli O157:H7 outbreak associated with swimming in battle ground lake, Vancouver, Washington. Journal of Environmental Health 64, 16-20, 25, 26.

Sandvig, K., Garred, O., Prydz, K., Kozlov, J.V., Hansen, S.H., van Deurs, B., (1992). Retrograde transport of endocytosed shiga toxin to the endoplasmic reticulum. $\mathrm{Na}$ ture 358, 510-512.

Schmitt, C.K., McKee, M.L., O’Brien, A.D., (1991). Two copies of shiga-like toxin ii-related genes common in enterohemorrhagic Escherichia coli strains are responsible for the antigenic heterogeneity of the o157:H- strain e32511. Infection and Immunity 59, 1065-1073.

Sebbag, H., Lemelle, J.L., Moller, C., Schmitt, M., (1999). Colonic stenosis after hemolytic-uremic syndrome. European Journal of Pediatric Surgery 9, 119-120.

Siegler, R.L., (1994). Spectrum of extrarenal involvement in postdiarrheal hemolytic-uremic syndrome. The Journal of Pediatrics 125, 511-518.

Sonntag, A.K., Bielaszewska, M., Mellmann, A., Dierksen, N., Schierack, P., Wieler, L.H., Schmidt, M.A., Karch, H., (2005a). Shiga toxin 2e-producing Escherichia coli isolates from humans and pigs differ in their virulence profiles and interactions with intestinal epithelial cells. Applied and Environmental Microbiology 71, 8855-8863.

Sonntag, A.K., Zenner, E., Karch, H., Bielaszewska, M., (2005b). Pigeons as a possible reservoir of shiga toxin $2 \mathrm{f}-$ producing Escherichia coli pathogenic to humans. Berliner und Münchener Tierärztliche Wochenschrift 118, 464-470.

Strockbine, N.A., Marques, L.R., Newland, J.W., Smith, H.W., Holmes, R.K., O’Brien, A.D., (1986). Two toxinconverting phages from Escherichia coli O157:H7 strain 933 encode antigenically distinct toxins with similar biologic activities. Infection and Immunity 53, 135-140.

Tarr, P.I., Gordon, C.A., Chandler, W.L., (2005). Shiga- toxin-producing Escherichia coli and haemolytic uraemic syndrome. Lancet 365, 1073-1086.

Trevena, W.B., Hooper, R.S., Wray, C., Willshaw, G.A., Cheasty, T., Domingue, G., (1996). Vero cytotoxin-producing Escherichia coli o157 associated with companion animals. The Veterinary Record 138, 400.

Urdahl, A.M., Beutin, L., Skjerve, E., Zimmermann, S., Wasteson, Y., (2003). Animal host associated differences in shiga toxin-producing Escherichia coli isolated from sheep and cattle on the same farm. Journal of Applied Microbiology 95, 92-101.

Wasteson, Y., 2008, Epidemiology of vtec in non-ruminant animals, In: Verocytotoxigenic E. coli. Food \& Nutrition Press, Inc., pp. 149-160.

Wasteson, Y., Arnemo, J.M., Johansen, B.K., Vold, L., Mathiesen, S.D., Olsen, M.A., Wiig, O., Derocher, A.E., (1999). Analysis of faecal samples from wild animals for verocytotoxin producing Escherichia coli and e coli o157. The Veterinary Record 144, 646-647.

Wasteson, Y., Lund, A., Olsvik, O., (1992). Characterization of escherichia-coli strains isolated from pigs with edema disease. Veterinary Microbiology 30, 179-190.

Wells, J.G., Shipman, L.D., Greene, K.D., Sowers, E.G., Green, J.H., Cameron, D.N., Downes, F.P., Martin, M.L., Griffin, P.M., Ostroff, S.M., et al., (1991). Isolation of Escherichia coli serotype O157:H7 and other shiga-liketoxin-producing E. coli from dairy cattle. Journal of Clinical Microbiology 29, 985-989.

Wong, C.S., Jelacic, S., Habeeb, R.L., Watkins, S.L., Tarr, P.I., (2000). The risk of the hemolytic-uremic syndrome after antibiotic treatment of Escherichia coli O157:H7 infections. The New England Journal of Medicine 342, 1930-1936.

Zhang, W., Bielaszewska, M., Kuczius, T., Karch, H., (2002). Identification, characterization, and distribution of a shiga toxin 1 gene variant (stx(1c)) in Escherichia coli strains isolated from humans. Journal of Clinical Microbiology 40, 1441-1446. 